\title{
IMPEDIMENTS TO TAX COLLECTION OUTSIDE THE TAX LAW
}

\author{
PhILIP H. CoRNICK*
}

One wholesome by-product of the depression has been the growing recognition among public officials and civic agencies of the importance of well-drafted tax laws and of businesslike procedures for the assessment, levy and collection of taxes on real estate. In many sections of the country, the movement for the improvement of our statutes and our administrative competence has borne fruits which amply justify the enthusiasm of its advocates. The fact remains, however, that the unhealthy situation which exists with respect to tax collections in some jurisdictions has not proven readily susceptible to cure by the application of any of the remedies which have been, or which legally can be, made available in the pharmacopoeia of tax administration.

That some at least of the causes of this situation lie wholly beyond the reach either of the tax law itself or of the most competent administration thereunder is a fact which seems not to have been given sufficient weight even in the more searching of the studies of tax delinquency which have recently been made. When its existence has been recognized, the proposals for reform have been based too largely on assumptions which are valid with respect to certain classes of real estate only. Those assumptions may be summarized somewhat as follows: that all arrears of taxes on real estate can be traced to one or the other of two basic causes-either the sheer financial inability of the owner to pay his taxes, or his unwillingness to pay even though he be able to do so. The proposals for reform centering around these assumptions may be grouped under two headings: those designed to make it as easy as possible for distressed taxpayers to make complete or partial payments, and those designed to stimulate unwilling taxpayers, either by holding out inducements in the form of discounts or by resort to coercion in the form of penalties, tax sales and foreclosures. To the extent that a given tax roll is made up of properties whose owners can be reached by these means, these reforms have proven their effectiveness. This paper will be directed to the consideration of two types of situations which have resisted the tax reformer's therapy.

- B.S., 1903, University of Tennessee. Member, research staff, Institute of Public Administration, New York City. Author of chapters on tax administration in Buck's Municipal Finance, and of the sections dealing with tax administration and indebtedness in numerous survcy reports prepared for state and municipal governments. This paper is based largely on material collected by the writer in the course of work for the New York State Commission for the Revision of the Tax Laws, the Westchester County (N. Y.) Commission on Government, and the New York State Planning Council. 


\section{ACCIDENTS OF OWNERSHIP}

Unfortunately, several varieties of what might be called accidents of ownership militate against the usefulness of such remedies. When there is no clearcut and dominant interest in a given property which is sufficiently large to make it worth protecting against the imposition and foreclosure of tax liens, or when the ownership of that dominant interest is in itself estopped by legal, administrative, or economic obstacles from protecting itself, the most aggressive and competent tax collector, operating under broad powers, may still be impeded.

A few cases of this kind will be found even in the best of tax rolls. They are not due to bad administration either in the assessor's or in the collector's office; they cannot be eliminated by good administration on the part of any tax official. As long as they exist only in small numbers their untoward effects can be offset during the process of budgeting by the creation of reserves for delayed or uncollectible taxes. That has been done recently on a fairly large scale in jurisdictions which were compelled by the growing intensity of the depression to make the transition from an accrual to a cash basis of budgeting. There is a limit, however, to the creation of such reserves, because they can be made effective only by increased levies on the properties-which make up the remainder of the roll. The increased levies in turn may force properties which had formerly been good taxpayers into the class in which the dominant interest is no longer worth protecting against the foreclosure of the lien.

Now, what are the particular accidents of ownership which stand in the way of tax collections, and how do they arise? As has already been indicated, they exist in wide.variety, and are caused by divergent factors. Only a few partial and inadequate studies have as yet been made in the field-studies which provide the basis only for rough outlines of their nature and for approximate guesses as to their extent. Three clearly defined types will be discussed below.

\section{Properties in Receivership}

First in complexity, perhaps, are the cases involving the taxable real estate of in:solvent corporations which are in process of reorganization or liquidation. Because private creditors are subject to fewer trammels than municipal corporations in taking prompt steps to protect their interests, a corporation fighting against insolvency will as a rule go into arrears in taxes in order to conserve its slender resources in cash for meeting other claims. As a result, substantial tax arrears have generally accumulated against the real estate before action by a private creditor leads to the appointment of a receiver. The recurrent annual levies during the protracted receiverships which are only too common merely go to swell the already large volume of arrears. Even when the liens are offered for sale, private lien buyers are averse to bidding, and the city is forced to hold the lien. When, in a recent case, the city of Yonkers was con- 
sidering the advisability of foreclosing its tax lien on such a property, a federal judge sternly warned that the action would be deemed contempt of court. Beyond the creation of reserves for uncollectibles in each successive budget, it is obvious that a city is powerless to protect itself in circumstances of this kind. The situation can be ameliorated, if at all, only by reforms in the bunglesome procedures in insolvency cases, and by the recognition by the federal courts in practice of the accepted doctrine that liens for local taxes have priority over all private liens and encumbrances.

\section{Properties in Decedents' Estates}

Somewhat analogous to cases of this kind are those which arise in the interim between the death of a testator and the final distribution of the property in accordance with the provisions of the will. Taxes can and frequently do fall into arrears during such a period. In some instances, the estate finds itself in the position of being "land poor." In the case of large estates, other factors often intervene. Among these is the consideration that many able lawyers are poor business men, who do not always realize that dispatch in the closing of an estate may be of decided monetary advantage to the heirs. The situation is further bedevilled because the very delays which may be poor business from the standpoint of the client may be decidedly to the financial advantage of the attorney. The tax administrator is not quite so helpless in the face of situations of this kind as he is in connection with properties in the hands of a receiver, but even so, he can do little which will insure a steady flow into the treasury of the recurrent annual tax levies during the sometimes unduly extended period of transition in the title of properties in this group.

Except in municipalities whose economic stability depends largely on the operations of one industry, there is little danger that accidents of ownership of the two types just discussed will precipitate a situation which in itself will seriously cripple local finance. They are of importance in this discussion only because it would be difficult, in good times as well as in bad, to find a tax roll in any of our larger municipalities which does not contain a limited number of large taxable properties in these categories; because the number of properties in these classes tends to increase at the very time when depressions force other properties not subject to these accidents of ownership into the non-taxpaying classes; and because the effects of these unpredictable large cases, coupled with the more easily predictable arrears on a considerable number of smaller properties, may combine to undermine the ability of a municipality to pay its own bills when due.

\section{Properties Financed by Mortgage Certificates}

The third class of properties which may become non-taxpayers because of accidents of ownership is relatively much more important in many urban areas than the preceding groups, whether from the standpoint of numbers or from the standpoint of the volume of taxes involved. It is a by-product of one of the haphazard methods of private finance which was widely used a decade ago. The simple method of 
financing building operations that had formerly prevailed, in which a substantial equity gave security to a first and possibly a second mortgage held by responsible mortgagees, did not meet the needs of the financial wizards who rose to eminence during the boom. The owner of the property, whether individual or corporate, rarely had any substantial interest in one after another of the towering edifices which during the last decade pierced the sky in all of our rapidly growing cities. In all too many cases, the money for financing the entire enterprise, including fat profits for the promoters, had been obtained by the issuance of a mortgage, which in turn was subdivided into numerous certificates of participation, large and small. Such a mortgage was generally serviced by a corporation created for the purpose. It was usually guaranteed both as to principal and interest, in some cases by a corporation independent of the servicing corporation. When the real estate crash came, the only one of the many interests in such a property which was organized for immediate action was the ownership of the fee, but that interest frequently had little in the way of actual investment to protect. The dominant mortgage interest, on the other hand, which had made the only substantial cash investment in the venture, had not only been lulled into a false sense of security by the existence of the supposedly iron-clad guarantees, but it had also been so widely and loosely disseminated that when those guarantees proved worthless it found itself wholly without the means for protecting itself.

Thoroughgoing analyses of the influence on tax delinquency of this type of financing remain to be made. A hurried study made by the writer in Yonkers at the close of 1933, when current collections had dropped to 69 per cent of the levy, showed that of 89 apartment houses, with a capacity of 16 families or over which were located in the southwestern section of the city, 50 were in arrears on current taxes, and 23 were also in arrears for taxes of the preceding year. The larger and more costly buildings in this class were in arrears practically without exception. These large multifamily dwellings as a class were evidently more deeply in arrears than the taxable real estate in the city as a whole. A subsequent study also made by the writer in the adjoining city of Mt. Vernon revealed the fact that of the rr,396 taxable properties on the roll, 34 large improved properties ranging in assessed valuation between $\$ 100,000$ and $\$ 1,500,000$ were responsible in September I934 for 10.8 per cent of all the unpaid taxes and assessments of 1933 and prior years.

Time did not permit an analysis of the status of the properties in either city with respect to mortgages. The certificated mortgage was, however, widely resorted to in the construction of apartment houses, office buildings and theatres throughout the entire New York metropolitan area of which these two cities are parts; and the reports on one after another of such properties, made from time to time by the state superintendents of insurance and of banking, and by the recently created mortgage commission-official agencies to whom fell the task of protecting the scattered holders of mortgage certificates-indicate the extent to which the taxes thereon 
had been allowed to fall into arrears before the state intervened. While it has not been clearly proven, all available facts point to the conclusion that a large part of the tax delinquency on income-producing properties throughout the more densely built-up portions of New York City and of its suburbs at the end of 1933, was traceable to properties financed with mortgage certificates; and that the recovery in current and delinquent tax collections which has taken place since that time is attributable not alone to economic recovery and to improved tax administration, but also in large part to the insistence of the state agencies referred to that the certificate holders be protected by the payment of taxes.

We have dealt up to now with classes of properties which as a group are worth protecting against the imposition and foreclosure of tax liens. As soon as the more or less temporary obstacles which hamper the freedom of action of the dominant interests in the properties are removed, the properties in question resume their normal status as income producers for their owners and as taxpayers to government. Meanwhile, however, they may have forced the municipalities in which they lie to suspend payments on their own obligations.

\section{II}

\section{Properties in UNNeEded Subdivisions}

We come now to the second type of situation which resists tax reform. It is widely distributed throughout the extensive areas of prematurely subdivided land lying in the fringes of practically all our urban districts. Properties in this class can and frequently do suffer from badly involved titles which deprive the dominant interests of the freedom of action necessary for self-protection. But the basic diffculty lies in the fact that the properties themselves may be so incapable of producing present income, and the hope of future income may be so remote, that even owners who hold them free of all encumbrances save those involved in liens for taxes and special assessments may come to the conclusion that the property is worth less than the taxes. The problems created by this situation are serious, especially in suburban areas and resort cities. An unduly high proportion of the American municipalities which have not yet succeeded in adjusting defaults on bonded debt are in one or the other of these two classes.

It may be contended that the correction of such a situation is easily within the scope of good tax administration; that the assessor can and should reduce the valuations of such properties to a point where the owner could afford to pay taxes. Where fixed levies for local improvements have not already been imposed, such a plan may prove effective. On the other hand, it is possible to cite instances of subdivisions ranging in size from a few hundred to several thousands of lots, in which no local improvements have ever, been installed, and in which the lots are assessed at only five, ten, or twenty dollars each. The tax levies per lot amount to a 
few cents per year. Nevertheless, every lot in these subdivisions is now in arrears and has remained in that condition for decades.

Why, it may be asked, is it not within the scope of good tax administration to clean up such situations by tax sale? The answer to this question will vary from one part of the country to another. In some states, a tax title constitutes little more than a cloud on the title of the owner of record; in other states, a title based on a lien for taxes vests only after resort to the same procedure which the real estate law provides for the foreclosure of a mortgage. In either case, substantial costs over and above the arrears of taxes are involved before a public or private holder of a tax title or a tax lien can make his claim effective.

The problem of recovering by sale the amounts involved in levies on prematurely subdivided vacant lots even when they have a substantial value, is by no means simple when those levies include special assessments. Improvements installed during the latter part of the boom when design and specifications were on a lavish scale and costs of construction high, resulted in special assessments per lot which are unduly onerous from the standpoint of present day prices. Private individuals are not interested in acquiring the properties for the. sums involved in the levies already overdue. When future insta' nents of special assessment levies also remain to be paid, the private buyers avoid the property as they would a plague. When, as in some states; the lien for general taxes is separable from that for local improvements, and when the sale of a property for general taxes divests all other liens including those for special assessments, the problem of the collector of general taxes is somewhat simpler. The entire security, on the other hand, which underlies the so-called municipal bonds which had been issued for the street improvements, is wiped out, and the loss falls on the hoodwinked investors.

Another factor intervenes to complicate the situation. Two cases have come to the writer's attention in which local governments had acquired title to groups of vacant lots covered by restrictions on the value of the houses which could be erected thereon. Because $\$ 18,000$ will build a more pretentious house today than it would have done in 1927 , and because the demand for $\$ 18,000$ houses in those sections has almost ceased to exist, those lots are today practically unsalable. No amount of improvement in tax law or in tax administration per se will serve to make such properties, or the tax liens on them, convertible into cash.

How important have arrears on vacant lots been in the total arrears which confronted municipalities at the trough of the depression? Here again, not enough research has been done to provide a complete answer. In Manhattan Island in the

- City of New York, only three out of every too taxable properties are vacant lots. Only $\$ 1.50$ out of every $\$ 100$ of taxable value is on vacant lots. Under such, circumstances, even if all the vacant lots had ceased to pay taxes-which is not the casethe result would not be serious. On Staten Island, which is also in the City of New York, the situation is somewhat. more serious. There 52 out of every 100 pieces of 
property are vacant lots and more than $\$ 17$ out of every $\$ 100$ of taxable value is based on nothing more substantial than non-income-producing vacant lands not used for any purpose. It is probably significant that Staten Island, which has the greatest oversupply of lots in premature subdivisions in the entire city, should consistently throughout the depression have paid a smaller percentage of the general taxes levied on it than any other of the five boroughs. Figures as to how it fared with respect to levies for local improvements are not readily accessible.

\section{Around Buffalo}

Further testimony concerning the paralyzing effects of premature subdivision on tax collections is contained in a series of mimeographed tables issued by County Treasurer Charles Ulrich of Erie County, New York. In that county, which contains the city of Buffalo, the suburban cities (two in number) and the outlying towns ( 25 in number) contained 178,963 taxable parcels, of which 89,086 failed to pay their taxes for 1935. The liens were offered for sale. Private lien buyers took 2,I4I. The county was forced to buy in 86,945 . No count has been made of the number of improved properties which went to lien sale, but inquiry elicited the opinion that practically all of the improved properties in arrears were bought in by the private lien buyers, and that the liens acquired by the county consisted with few exceptions of those on vacant lots. More striking still, four of the suburban towns immediately adjacent to Buffalo had contributed 49,832 of the liens acquired by the county. One town alone; containing 36,630 taxable properties, was responsible for 21,172 of the liens which no private buyer would touch; another with 25,498 taxable properties was responsible for 14,699 of the county's unsalable liens.

No study has been made of the effect of local improvement levies on the arrears in those towns. The report of the New York State Tax Commission for 1934 provides the basis for the statement that 86.7 per cent of all the special district levies in the 25 towns of Erie County fell on properties within the four towns immediately adjacent to the city of Buffalo-the same towns which contained the largest number of properties subject to unsalable liens. Furthermore, the report of the county treasurer already cited shows that those same four towns have contributed 79.2I per cent of the face value of all the liens held by the county for taxes of $x 935$ and prior years, including the liens for county taxes on properties in the city of Buffalo and in the two smaller cities in the county. If the county-held liens on properties in the three cities are eliminated, the four towns which have the heaviest levies for local improvements, and the greatest surplus of prematurely developed vacant lots, are found to be responsible for 87 per cent of all the accumulated arrears in the 25 towns.

\section{In Westchester County}

Figures are also available for the county of Westchester, New York, in a report prepared for the Westchester County Commission on Government. That county lies adjacent to the City of New York and contains four cities and 18 towns. In 
1934, the tax rolls listed 222,802 separately described parcels of taxable property. Of that number only 90,678 contained structures of any kind. The remaining 132,124 properties consisted of vacant lots in subdivisions or vacant acreage awaiting subdivision. In the 18 towns and in the three largest of the four cities, an analysis of the lien registers revealed the fact that 60,294 properties were in arrears for general taxes and local improvement levies to an aggregate sum in excess of $\$ 13,800,000$. Of that number, 12,173 were improved properties, including factories in the hands of receivers and large structures erected from the proceeds of the sales of mortgage certificates. In spite of the substantial sums due on properties in this group, the vacant lands were responsible for 52.5 per cent of the accumulated arrears of taxes and local improvement levies for 1933 and prior years. When the 18 towns alone were subjected to scrutiny, it developed that there was a close correlation between the burden of local indebtedness and tax levies on the one hand and the extent of premature subdivision on the other.

\section{Avenues to Reform}

Analysis would no doubt show that among the large number of cities which had previously been in default but which have succeeded in resuming payments, many were the victims of the obstacles to tax collection which were discussed earlier in this paper-obstacles which for the time being were insuperable from the standpoint of the tax collector, and which were removed by procedures in fields of law not directly related to the tax law itself.

In the fields of law having to do with the transition of title to real estate under procedures supervised by the courts and administered by attorneys, much could probably be accomplished by a more businesslike and more ethical approach to the matters involved. The sources of the third and more serious group of obstacles, those created by our recent resort on a large scale to certificated mortgages,-are probably being removed in part by amendments to existing mortgage, banking, and insurance laws.

Even after these changes shall have been made, certain things will remain to be done within that "no man's land" surrounding our real estate law in which the conflicts between public and private rights in lands arise. Under the leadership of specialists in the law of city planning, we have succeeded in driving certain vulnerable salients into that area through our extension of public control over private land uses under the police power. In the face of the disruptive forces generated by speculative inflations in land prices which occur from time to time, those controls in their present forms have proven themselves relatively ineffective in preventing either the overintensive development of lands near our urban centers or the overextensive developments in the urban fringes. These inflations, and the inevitable deflations which follow in their train, have been so devastating in their effects on the orderly processes of governments and of individuals alike, that their control becomes a matter of primary importance-a challenge to the best thought of lawyers, economists, and political scientists alike. 